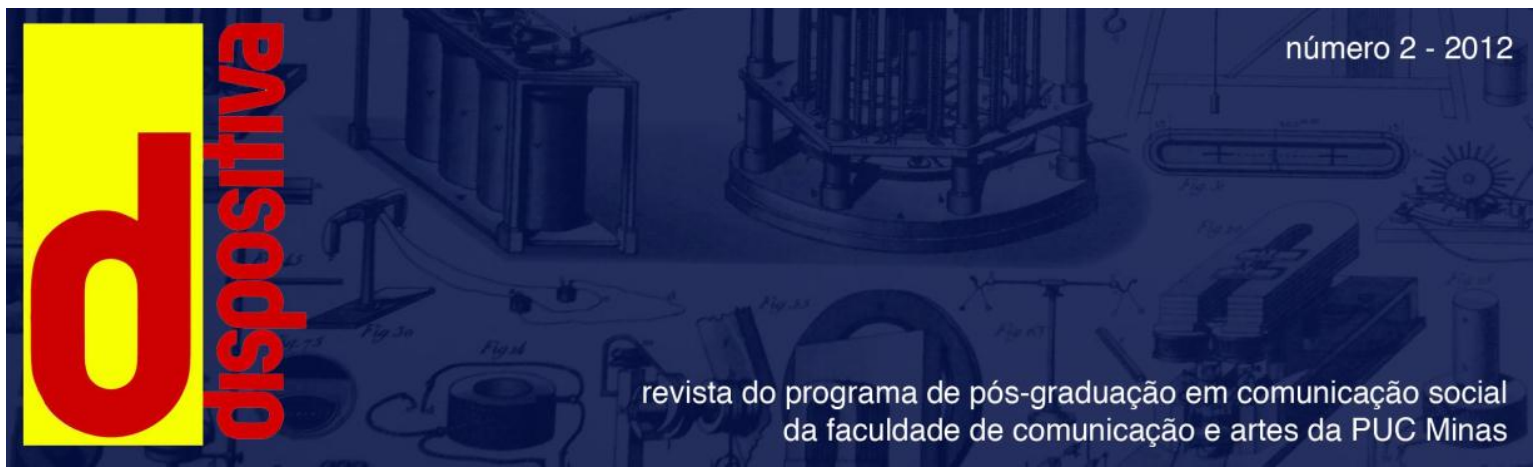

\title{
O Efeito Fabril que o Newsmaking não vê: o que dizem outras áreas do conhecimento sobre os constrangimentos sofridos por jornalistas na Fábrica de Notícias // The Fabril Effect that the Newsmaking does not see: what other areas of knowledge say about the constraints suffered by journalists in the News Factory
}

\author{
Robson Dias ${ }^{1}$
}

\begin{abstract}
Resumo
A notícia faz parte de uma construção social da realidade. Trata-se de um bem capital, fabricável. Existe um mercado noticioso que produz notícias e as comercializada. Se a empresa jornalística pode ser comparada a uma Fábrica de Notícias, com linha de montagem de produção de notícias (Newsmaking), o jornalista seria o operário desse negócio. Em Teorias da Comunicação, estuda-se muito os constragimentos, gratificações e penalidades do trabalho e do sistema organizacional no qual o jornalista está inserido. Mas tal arcabouço teórico não consegue vislumbrar, em termos práticos, situações de doenças, estresse e outros males ao indivíduo. O artigo visa compilar estudos da Psicologia Social, Ciência da Informação e da Comunicação que relatem sobre o sofrimento dos jornalistas neste contexto.
\end{abstract}

Palavras-chave: Jornalista, trabalho, newsmaking

\begin{abstract}
The news are a social of reality construction. They are a capital manufacturable. There is a market which produces news stories and marketed then. If a news organization can be compared to a news factory, with assembly line production of news (Newsmaking), the journalist would be the operator of this business. In Communication Reseach, we study the constraints, bonuses and penalties of work and organizational system in which the journalist is inserted. But this theoretical unable to discern, in practical terms, situations of illness, stress and other ailments to the individual. The article aims to compile studies of Social Psychology, Information Science and Communication to report on the plight of journalists in this context.
\end{abstract}

Keywords: Journalist, work, newsmaking

\footnotetext{
1 Doutorando em Comunicação do Programa de Pós-Graduação da Faculdade de Comunicação da Universidade de Brasília (PPGFAC/UnB).
} 


\section{Introdução}

Os estudos de Newsmaking por terem um viés sociológico abordam a questão dos constrangimentos organizacionais de forma abstrata. A categorização temática das situações faz com que as abordagens sejam feitas frequentemente com apontamentos do tipo: "velocidade na realização das tarefas", "excesso de trabalho", "trabalho ininterrupto", "escassez de tempo na vida privada", "pressão para fechamento de edições”, "baixa remuneração", "expectativas da chefia” (TRAQUINA, 1993).

A Sociologia tem por objeto o estudo das sociedades humanas em geral e de todos os fenômenos sociais. Desta forma, analisa as relações entre pessoas que vivem numa mesma sociedade ou grupos sociais e a interação destes com a sociedade. A perspectiva Newsmaking tem o mesmo olhar, mas especializado nas relações entre os jornalistas no ambiente organizacional. Neste sentido, tomamos a decisão de exemplificar alguns resultados específicos de pesquisas, que não podem ser generalizados, mas que permitem vislumbrar efeitos oriundos do trabalho e sofrimento do jornalista.

Optamos por dar mais vida ao contexto do trabalho e do sofrimento saindo um pouco da influência sociológica dos estudos de Newsmaking. Queremos abordar pesquisadores e jornalistas que falam sobre situações mais exemplificadas, ou até concretas, como: valor dos salários, jornada, hora-extra, benefícios, problemas de saúde, assédio moral, precarização do ambiente de trabalho (poluição/ruído/ trânsito), suporte recebido na realização de tarefas, vício em trabalho, segurança, capacitação, lazer, aprendizado, senso crítico, auto-estima, disponibilidade, fadiga, energia, dor, desconforto, sono, repouso, perspectivas de carreira e relações humanas. Todos esses fatores são relevantes para a satisfação e motivação dos jornalistas nas rotinas produtivas e o rendimento no trabalho. Em vista de que, o trabalho também afeta o profissional.

Abordaremos pesquisas e alguns depoimentos de profissionais, coletados nesses estudos, para recordar tópicos do arcabouço teórico de Newsmaking. Esse panorama proporciona uma melhor contextualização do labor, ambiente de trabalho, pressões e constrangimentos sofridos. $\mathrm{O}$ intuito é de exemplificar situações e conseqüências do labor e do ambiente de trabalho do jornalista. 


\section{O contorno da Fábrica de Notícias}

Como abordagem sociológica, o Newsmaking insere-se no campo da Sociologia do Conhecimento no tema da construção da realidade, a qual estabelece uma tensão entre fato (acontecimento) e fato jornalístico (notícia). A Teoria explora a realidade que os meios de comunicação reportam à sociedade, as exigências cotidianas no processo de produção da notícia, além da influência dos relatos jornalísticos sobre a imagem que o leitor faz do mundo. Também pertence ao ramo da Sociologia dos Emissores (WOLF, 2003).

No Newsmaking há também a influência da Sociologia das Profissões em dois aspectos: o primeiro é o de que as normas profissionais superariam as distorções subjetivas do indivíduo (1); e o segundo é voltado para a análise da lógica dos processos de produção da notícia e o tipo de organização do trabalho no Jornalismo $(2)^{2}$.

Durante o estudo de alguns autores da perspectiva Newsmaking, em Teorias da Comunicação, frequentemente nos deparamos com autores como Breed (1993, p. 152) que postulam sobre a relação de empregados e patrões num sistema organizacional jornalístico. $\mathrm{O}$ autor inclusive identifica o conformismo como efeito de adesão à estrutura organizacional, na tentativa dos jornalistas evitarem constrangimentos no Trabalho. Teoricamente, essa adesão está ligada a seis fatores: autoridade institucional e as sanções (1), sentimentos de dever e estima para com os chefes (2), aspirações de mobilidade profissional (3), ausência de grupos de lealdade e conflito (4), prazer da atividade (5) e notícia tornar-se um valor (6).

Quando estudamos autores como Breed (1993), raramente, conseguimos vislumbrar alguns efeitos do trabalho, das gratificações e penalidades sofridas por um profissional dentro da estrutura organizacional. Só temos a dimensão disso quando outras áreas do saber levantam dados sobre este universo, que não são vistos no escopo teórico de Newsmaking.

Não estamos aqui argumentando que a perspectiva Newsmaking seja equivocada ou imprecisa. De forma alguma. Mas estamos, sim, tentando demonstrar que existem situações de ordem prática que muitas vezes não conseguimos vislumbrar em contato com este arcabouço teórico. Vejamos uma pesquisa sobre qualidade de vida e

\footnotetext{
${ }^{2}$ Para Hohlfeldt (2001, p. 203), o Newsmaking está mais para uma Teoria do Jornalismo do que propriamente da Comunicação.
} 
saúde psíquica de jornalistas na região de Campinas (São Paulo).

Na pesquisa, Qualidade de vida de jornalistas da macro região de CampinasSP, há uma proposição interessante de Beraquet (2005. p. 90), autora, sobre o desgaste na relação entre patrões e jornalistas, seguida de um alerta aos patrões e categorias de classe sobre a saúde psíquica dos empregados:

\begin{abstract}
Os dados obtidos no estudo não podem ser generalizados, uma vez que a amostra de estudo corresponde a 7,53\% da população de jornalistas sindicalizados da macroregião de Campinas/SP, mas são sinalizadores importantes e apontam para a necessidade de que haja a inclusão na grade curricular do curso de Jornalismo de disciplinas que contemplem questões ligadas à Saúde Mental e os riscos ocupacionais envolvidos, bem como, os órgãos de classe e empregadores viabilizem a criação de centros de apoio psicossocial a esta categoria profissional e que haja uma fiscalização rigorosa quanto às horas semanais trabalhadas, objetivando-se o cumprimento das leis trabalhistas do país quanto às jornadas de trabalho.
\end{abstract}

Um dado da International Stress Management Association no Brasil (ISMABR), associação que estuda estresse e qualidade de vida em diversas profissões, coloca os jornalistas em $5^{\circ}$ lugar dentre as profissões mais estressantes do mercado de trabalho (área de segurança, motoristas, controladores de vôo, executivos, bancários) ${ }^{3}$.

Nassar (1990), em Doenças profissionais em comunicação social ${ }^{4}$, faz um mapeamento de doenças mais frequentes neste grupo de profissionais: problemas estomacais, cardíacos, alcoolismo, tabagismo, dependência química de drogas, estresse, problemas de coluna. Numa amostra de dois anos, observou-se que o câncer e o infarto foram as doenças que mais causaram morte de jornalistas. Dos 55 casos analisados no escopo da pesquisa, 10 mortes foram por câncer (18\%), 25 por problemas do coração $(45 \%)$, cinco por acidente (9\%), quatro por problemas no cérebro (7\%), quatro por problemas do pulmão (7\%), dois tiveram septicemia (3\%), dois suicídios (3\%) e um sem causa anunciada.

Heloani (2005), em Mudanças no mundo do trabalho e impactos na qualidade de vida do jornalista ${ }^{5}$, identifica que o jornalista está submetido a diversas situações de alta carga de estresse, sendo obrigado a se adaptar a gestões organizacionais quase draconianas.

O Departamento de Saúde e Previdência da Federação Nacional de Jornalistas (FENAJ) já relatou uma pesquisa realizada pelo jornalista José Augusto

\footnotetext{
${ }^{3}$ Fonte: ISMA-BR (www.ismabrasil.com.br), acessado em 12-12-2011.

${ }^{4}$ NASSAR, Sílvio Júlio. Doenças profissionais em Comunicação Social. UFRJ.1990(mimeo)

${ }^{5}$ HELOANI, José Roberto Montes. Mudanças no Mundo do Trabalho e Impactos na Qualidade de Vida do Jornalista. FGV-SP. 2005
} 
Guto Camargo (SJSP), no Programa de Aperfeiçoamento da Informação de Mortalidade (Pro-Aim), em São Paulo, na qual aponta que as maiores causas identificadas de óbitos, entre os jornalistas. As doenças isquêmicas do coração lideram o ranking do estudo, que contabiliza 64 mortes deste tipo de óbito entre os anos 1996 e 2003, seguidas por diversos tipos de câncer: 62 ocorrências, no mesmo período ${ }^{6}$.

O Departamento de Saúde e Previdência da FENAJ chega a dizer que, "mesmo sem qualquer metodologia científica", os jornalistas podem observar na prática que o ambiente das redações é altamente estressante e as conseqüências desta situação são sentidos no cotidiano; hipertensão, doenças do coração, sofrimento mental, distúrbios no sono e no apetite, entre outros vários males. E reforça que, vários profissionais também relacionam o uso de álcool e drogas a uma forma de reação psicológica a este ambiente opressivo. Sem falar em agravos à saúde dos jornalistas, causados pelo exercício profissional, com as Lesões por Esforços Repetitivos (LER), Doenças Osteomusculares Relacionadas ao Trabalho (DORT).

O Departamento de Saúde e Previdência da FENAJ ainda chama atenção para os riscos da profissão. E diz que a maioria dos jornalistas não relaciona ao trabalho alguns agravos e óbitos ocorridos por decorrência de fatores externos, ou seja, a violência que vitimou dezenas de profissionais em jornada de trabalho. E cita como efeito da violência urbana, suscetível a jornalistas, assaltos, sequestros ... e situações mais graves como o assassinato do repórter Tim Lopes (idem).

No artigo, versamos sobre essas implicações práticas que não aparecem no arcabouço teórico de Newsmaking. Teóricos como Breed (1993) jamais poderão relatar o sofrimento psíquico, quadros clínicos e doenças que tiveram sua origem em ambientes organizacionais, como efeito de Gratificações e Penalidades da cultura organizacional. É sobre estes dados que vamos vislumbrar efeitos da Fábrica de Notícias e do trabalho jornalístico na saúde e no cotidiano de profissionais. O olhar é orientado por estudos da Psicologia Social, Ciência da Informação da própria Comunicação.

\section{Efeito Fabril: as consequências da rotina produtiva pela Psicologia Social}

Ferraciolli (2000) pesquisou a qualidade de vida dos jornalistas, por demanda do Sindicato dos Jornalistas Profissionais do Paraná. O pesquisador fez 19 entrevistas

\footnotetext{
${ }^{6}$ FENAJ - Teses e Dissertações. Acessado em 14-12-2011. Disponível em: http://www.fenaj.org.br/federacao/congressos/xxxi_cnj_teses_mocoes.htm
} 
semi-estruturadas sobre as condições de trabalho jornalístico no estado e sua consequiência na vida pessoal. Como resultado da pesquisa, ele identifica algumas contradições no comportamento dos jornalistas e as classifica em cinco categorias.

Na categoria número 1, Tudo é ruim, mas não largo a profissão: os jornalistas vivem com salário ruim; não participam das decisões salariais; o trabalho prejudica o convívio familiar, é desgastante e estressante; têm atividades diárias intensas frente a um computador (o que lhes causa problemas visuais, Lesão por Esforços Repetitivos), têm problemas de sono, mas vivem ligados no trabalho. Não desejam largar o trabalho, mas queixam-se de problemas gerados por ele; não pretendem desistir da profissão, mas não relatam não estar resistindo aos problemas de saúde advindos dela.

Sobre a baixa remuneração, falta de valorização da profissão, pouca visibilidade institucional, Ferraciolli (2000) destaca algumas falas:

"Eu não tenho muito planejamento no mês, não posso fazer compras a prazo, meu salário nunca vai sair no dia eu imaginar que vai sair, sai num dia, sai no outro, não há uma constância"

"Eles na ligam para esse seu lado. Eu vejo pessoas que vão trabalhar sem almoçar, como é que essa pessoa consegue ter cabeça para criar uma imagem? Às vezes, a pessoa com o estômago vazio fica pensando em casa, o que é que vai levar para casa? Para a família? Tem empresas que dão vale-refeição. São poucas. Vale-transporte também são poucas. Mas todas as empresas deveriam dar pelo menos alimentação"

"Sabe, elas não se preocupam em falar da qualificação, não se vê empresa oferecendo proteção ao jornalista, o jornalista também tem que se reciclar, ter cursos. Isso é importante para a empresa e para o jornalista, que o jornalista vá a conferências, vá a congressos, que aprenda informática, que hoje tomou conta da nossa profissão"

"Chega a um patamar que vai estar estagnado e aí você diz: poxa, tem um cara que tem 20 anos de profissão, né? E tá ganhando um salário que um cara que tá entrando no jornalismo muitas vezes tá ganhando. Essa falta de valorização da profissão, de valorização, eu digo, tanto na questão salarial quanto na própria questão... do empregador te valorizar um pouco mais"

"Eu sou sempre o lado do pessoal mais fraco para enfrentar o patrão. O que ele falar tá falado, então eu me sinto inferior e não consigo superar isso"

"Será que o trabalho do jornalista é algo melhor para a sociedade? Será que é importante? Porque será que eu tenho que levar tanta notícia? Vou lá, morre um cidadão, são notícias econômicas, políticas. Por que tem que ser tanta notícia? Será que tem gente que lê tudo isso?"

"E aí essas duas coisas me assustaram bastante, porque eu tava ganhando pouco para sofrer esse tipo de ameaça e para passar por esse tipo de perigo, acidente. Acordei para esse troço" (FERRACIOLLI, 2000, p. 87-113)

Na categoria número 2, Ritmo frenético é atraente, porém queixam-se por falta de tempo livre: a velocidade do trabalho é entendida como adrenalina e foi o que 
os seduziu para a área desde os bancos de formação universitária. Trabalham sempre correndo, produzindo em velocidade e qualidade, omitem problemas de saúde, porém vivem cansados e estressados. Procuram não viver o jornalismo em tempo integral, mas confessam estar conectados à redação 24 horas. Alguns depoimentos coletados pelo autor relativos à velocidade na realização das tarefas, ao excesso de trabalho e ao trabalho ininterrupto são:

"Tem um horário de fechamento que você tem que cumprir, isso é uma coisa que você tem que completar todos os dias, né? Então, é uma coisa que você não tá legal ou você tem uma dor de estômago e você pode deixar pra fazer no outro dia. Não, a notícia tem que ser feita naquele dia, tá te fazendo mal, mas tem que completar o trabalho naquele dia, né?"

“Acordo de manhã lá pelas 8 horas, faço cafezinho preto, me visto já correndo, o telefone tá tocando em casa, as pessoas querendo dar entrevista, já ... já começa com o jornal"

"Nunca tive, mas já sofri muito risco, você tá com pressa na estrada pra fazer cobertura de algum acidente, você vai até na contra mão, pois,por exemplo, na serra você tem que chegar logo no local mas não tem como devido o engarrafamento, então você via contramão, segue ambulância. Você tem que ter um treinamento desse risco, o motorista tem que ter treinamento"

“eu me acordo praticamente às 6:30 horas. Eu saio de casa por volta das 8:15 e 8:30, vou direto para a secretaria e, agora é o caso, vou para o departamento de polícia civil, vou para o gabinete, ali fico das 0:00 às 12:00hs. Necessariamente não preciso ficar lá dentro, pois, às vezes há um chamado para algum material do chefe ou secretário. Volto para casa e 13:15 e 13:30 já estou de volta na gazeta, daí, sim, como sou da parte de diretoria de polícia entro 13:30 e o meu horário de sair é imprevisível, posso sair às 19:30 como as 22:30 até 23:00hs. Praticamente essa tem sido a minha vida nesses últimos anos, nesses últimos meses, isso sem contar sábados e domingos. Foram mais de 15 anos trabalhando, então, domingo se torna um dia normal na semana"

"O jornalista tem uma ilusão de lazer, porque quando ele vai no carnaval ele tá trabalhando, é muito diferente, no Natal ele tá trabalhando, no ano novo ele vai à festa mas vai a serviço, tem um parque novo na cidade ele vai trabalhar"

"Quando estou em casa eu vejo no jornal uma matéria sobre frigorífico, quando eu chego lá a notícia já está rolando e a gente não tem carro, né, então eu corro atrás disso até começar o meu expediente. Ele começa às 05 horas, mas antes disso eu ligo pra pegar uma imagem (...) A gente tem que ficar ligado o dia todo. Tenho que estar de olhos abertos 24 horas por dia, basicamente, quer dizer, quando você vai para casa você continua trabalhando normalmente, não formalmente, mas você tem que ficar, tem que ficar ligado e final de semana também, ficar de plantão, eu tenho que ficar com o rádio e tv, dar uma olhada nas agências"

"Passo por um acidente de trânsito na rua e sua cabeça já pensa em termos de notícia e não na pessoa que está morta, será eu o jornal sabe disso, então você está na frente do cadáver e não pensa na vítima, pensa em ligar pro jornal" (FERRACIOLLI, 2000, p. 59-64) 
Na categoria número 3, Para trabalhar tem que ter cabeça boa, mas todos ficam com a cabeça ruim: relatam que têm saúde mental quando estão com a cabeça boa, porém vivem com desgaste mental e cabeça ruim (doentes, cansados, estressados).

"Eu mesmo já adoeci durante umas duas vezes... É aquela coisa. É o tempo, é a consciência que somatiza, sabe como? Não tem motivo nenhum para estar mal, mas muitas vezes é uma época que estou dormindo bem, me alimento bem, mas por conta desses problemas a gente acaba tendo uma febre, uma gripe, uma dessas oportunidades, assim, doenças oportunistas, baixa resistência"

"Eu tenho que conviver com meu problema, porque largar de trabalhar eu sei que eu não quero e só vou curar dessa doença quando eu parar de trabalhar"

"São agressões que acontecem no cotidiano, e aí vem a pressão psicológica que você vai fazer um trabalho, você fica tenso. A hora que você vai sair para fazer um trabalho importante você fica meio preocupado com medo de gravar, então existe essa tensão aí que afeta psicologicamente qualquer profissional, né?” (FERRACIOLLI, 2000, p. 122)

Na categoria número 4, Profissão não interfere na família, porém, descrevem de forma vívida os problemas familiares: quando relatam a postura da família frente à forma como o trabalho está organizado, pois, dizem não ter problemas familiares e, ao mesmo tempo, relatam as cobranças dos familiares pela ausência constante. Quatro entrevistados passaram pelo processo de divórcio após ingressarem na profissão”. O autor destaca a fala:

"Pra quem é jornalista e é casado com alguém que não é da área, às vezes, é complicado, muita viagem ou horário de trabalho, você não tem uma confiança. 6 horas da tarde você bate o cartão e vai embora pra casa, um dia até você consegue chegar cedo em casa, outro dia de madrugada, a pessoa fica ..., né? Não dá pra programar alguma coisa, chega na hora você está escalado pra fazer alguma coisa e tem que desfazer o programa familiar"

$\mathrm{Na}$ categoria número 5, Apresentam conceitos amplos de saúde, porém relatam vividamente os problemas com doenças geradas no trabalho ${ }^{7}$ : o autor identifica que o fato de os jornalistas omitirem desconforto com problemas em vista de prejudicar sua imagem de produtividade e disposição. Ferraciolli relata que só admitem que têm algum incômodo na esfera privada. No ambiente organizacional, mascaram. Em relação a problemas de saúde e agressões físicas, o autor destaca no escopo da pesquisa as falas:

"Eu já machuquei meu pé trabalhando, tirei o menísculo fora do lugar trabalhando, são coisinhas pequenininhas e tal, mas a gente nem comenta porque isso no dia a dia acontece com todo mundo, mas acontece" 


\begin{abstract}
"Bom, os repórteres cinematográficos é ... tem várias coisa que a gente pode relatar aqui, por exemplo: as câmeras que você usa, as câmeras que os repórteres saem todos os dias, é ... são câmeras pesadas, só usa de um lado, sempre usa o lado direito, tem que usar o lado direito, com o tempo, evidentemente vai dobrando a coluna, vai pensado, pesando, você tem um desvio de coluna. Nós temos um caso aí de um amigo nosso que ele foi operado. Ele não pode mais exercer a função dele $100 \%$, ele continua trabalhando mas só sai com tripé, ele já não tem condições de colocar no ombro, passou por uma cirurgia delicada até, né, hérnia de disco e tal, e sai e continua trabalhando, mas com tripé, em virtude de carregar a câmera com peso"
\end{abstract}

"Eu sofri três anos com uma tela que era praticamente apagada, eu não usava óculos até então, faz agora um ano que eu não consigo largar meus óculos e só está aumentando porque ela era praticamente invisível, tinha que dar o máximo de mim"

"Logo que eu tinha entrado no jornal, há uma semana que eu estava lá eu sofri um acidente super grave que eu tive sério risco de morte, mas eu tive uma equipe médica muito eficiente, mas a coisa foi feia mesmo, foi bravo mesmo. Foi durante uma reportagem, nós estávamos na preferencial e um caminhão atravessou a preferencial e foi horrível"

"Eles arrancaram o cabo do vídeo dele, da câmera dele e foi agredido com o próprio cabo, né? São agressões que acontecem no cotidiano"

"Batemos o carro, eu bati o olho, o óculos por sorte não quebrou, mas afundou no meu olho e assim foi aquele olho roxo e... pó pouco o acidente, o motorista tirou o lado dele e o meu lado que bateu atrás de um ônibus" (FERRACIOLLI, 2000, p. 77-87)

Os depoimentos coletados na pesquisa de Ferraciolli (2000) foram enunciados no artigo para podermos visualizar melhor o contexto das rotinas produtivas. Percebemos, muito além do arcabouço teórico de Newsmaking, que as condições de exercício da profissão são muitas vezes precárias, ao menos a julgar pelo escopo de pesquisa do autor em questão. Contudo, ressaltamos que não é possível fazer correspondência de nenhuma conclusão de Ferraciolli (2000) com Newsmaking, guardando o rigor científico da nossa pesquisa. Mas tomemos esses tópicos como leitura para a contextualização da complexidade da Fábrica de Notícias.

\title{
Efeito Fabril: consequências da rotina pela Ciência da Informação
}

Saber (2006, p. 20) pesquisou os efeitos da sobrecarga da informação no cotidiano de redações de Campo Grande (MS). A autora constatou que os jornalistas tem sido afetados pelo bombardeio de informação apresentando falhas na memorização, falta de concentração, ansiedade e irritabilidade entre outros aspectos ${ }^{8}$.

\footnotetext{
${ }^{8}$ As patologias do estudo são:

-Informatose (distúrbios ou doenças causadas por excesso de fluxo de mensagens informacionais);

-Cibernose (atrofiamento de funções humanas por uso de computador); e
} 
Saber (2006, p. 204) mostra ainda que rendimento profissional foi atingido por meio das dificuldades em filtrar a grande quantidade de notícias e como conseqüência, o produto final acaba sendo prejudicado com a velocidade dos fatos e a falta de tempo para apurar as informações. No escopo da pesquisa, foram entrevistados: 4 jornalistas de webjornalismo, 4 de jornal impresso e 3 de telejornalismo.

Saber (2006), pela perspectiva da Quantidade de Informação, identifica como os fenômenos que mais atingem os jornalistas são: a fadiga (28\%), a neurose (25\%), o vício (18\%), a intoxicação (14\%), a cibernose (7\%) e a informatose (4\%).

A autora considera que os fenômenos ligados à sobrecarga de informação, a intoxicação da informação, a fadiga da informação, a neurose informacional, o vício da informação, a cibernose e a informatose são apresentados como doenças entre os jornalistas do escopo. E que o resultado da pesquisa é uma auto-análise que acaba por detectar que dores de cabeça, irritabilidade, falhas de memória e falta de concentração não são sinais de que os jornalistas sejam incapazes para o trabalho; mas, sim, de que estão sendo submetidos a uma grande quantidade de informações que tem trazido reflexos na saúde mental, física e psicológica desses profissionais (SABER, 2006, p. 211).

Dos percentuais coletados como resultado da pesquisa, Saber (2006) comenta que o percentual de $28 \%$ dos jornalistas de sua amostra indica que a fadiga é o fenômeno que mais afeta o cotidiano das redações. Em segundo lugar está a neurose informacional, com percentual de $25 \%$ dos entrevistados. A autora considera que esse fato tem origem na ansiedade em conseguir informações, hábitos e sentimentos que o próprio indivíduo alimenta (os sintomas são a irritabilidade, alteração de humor, dificuldades em adormecer e distúrbios da memória). Em sua análise,

\begin{abstract}
Tanto o ambiente de trabalho nas redações quanto o próprio profissional são responsáveis pelos efeitos causados pela sobrecarga de informação. Nessa luta para divulgar notícias em primeira mão, correndo contra a velocidade da informação o jornalista precisou desenvolver novas habilidades, descobriu que é necessário se adequar a um novo perfil de profissional para se encaixar nas exigências do mercado da comunicação de hoje. Usar com destreza as ferramentas de busca pela Internet, ter comprometimento profissional na hora de checar as denúncias, não se entregar ao fenômeno de copiar e colar são atitudes que devem fazer parte da postura dos profissionais, mas a pesquisa apontou que geralmente não é isso que acontece. A notícia tem sido prejudicada por vários motivos que vão desde a pressa na hora de redigir até o surgimento de informações desencontradas e equivocadas. Para os profissionais, um sentimento de frustração impera porque, de acordo com a avaliação deles, as notícias andam sendo tratadas de forma superficial e padronizadas (SABER, 2006, p. 212).
\end{abstract}

-Fadiga informacional (entre os sintomas do processo esta a paralisia da capacidade analítica, o aumento das ansiedades e das dúvidas, a inclinação para decisões equivocadas e até levianas). 
Mais especificamente sobre a rotina produtiva, Saber (2006) pontua:

Sobrecarregados com a rotina, os jornalistas apresentam falhas na memorização, na concentração e queda na produtividade. O profissional da comunicação se vê envolvido nessa guerra constante de ter acesso, de produzir em grande quantidade, acabando por ser influenciado a se render ao ritmo alucinado e frenético que domina as redações. As entrevistas apontam que por conta da sobrecarga, o jornalista acaba por limitar seu convívio social e familiar pela opção de trabalhar muito durante um período prolongado e se esgotar fisicamente, intelectualmente e emocionalmente com sua atividade profissional (idem).

Sobre a percepção das condições de trabalho, Saber (2006) considera a rotina produtiva "completamente atordoada". Para a autora, o ambiente em que "telefone toca sem parar", "profissionais recebam uma enxurrada de e-mails" e a ansiedade devido à concorrência de "cada nota divulgada pelos sites estaduais e nacionais" fazem com que os jornalistas sejam "desafiados a lidar com problemas como a falta de tempo para se abastecer de informações", tenham "dificuldades em filtrar a informação" e ainda de "encontrar um novo foco que possa definir prioridades numa corrida constante contra a concorrência”. Para a autora,

Diante desse ritmo que alguns entrevistados preferem chamar de fabril percebe-se que o jornalista não consegue seguir no mesmo ritmo da tecnologia, da velocidade com que as informações se renovam, por isso, os informantes e informatas da Sociedade da Informação se descobrem em situações que demonstram dificuldades em assimilar conteúdo ao mesmo tempo em que não conseguem se desligar da informação (idem).

Saber (2006) categoriza como efeitos da sobrecarga de informação no cotidiano de redações ${ }^{9}$ :
a) Impossível fazer uma leitura detalhada e aprofundada sobre as notícias
b) Utilizam horários alternativos para conseguir acompanhar a evolução das notícias
c) Gostariam de poder dedicar mais tempo do dia para ler com mais calma as notícias
d) $\mathrm{O}$ excesso de informação traz dificuldades na hora de priorizar as notícias
e) Divulgar em primeira mão obriga os profissionais a fazer tudo ao mesmo tempo
f) A rotina frenética das redações desgasta e o excesso de informação sobrecarrega
g) Os jornalistas não conseguem se desligar da notícia
h) Até em sonho os jornalistas se vêem produzindo notícias
i) Os jornalistas percebem que é impossível absorver tantas informações
j) Tem dificuldades em controlar o volume de informação que chega às redações
1) Os jornalistas se sentem escravos do ritmo de trabalho que impera nas redações
m) Buscam aliviar o stress mental trazido pela grande quantidade de informações
n) Para alguns a sobrecarga de informação pode funcionar como fator estimulante

(SABER, 2006, p. 201)

Como efeitos da sobrecarga de informação sobre o jornalista, Saber (2006) conclui que as principais implicações sejam:

\footnotetext{
${ }^{9}$ SABER (2006) considera o ambiente das redações de mídia impressa e eletrônica. A análise da autora não versou sobre Telejornalismo ou Radiojornalismo.
} 
a) Fenômenos estudados até agora que estão ligados à sobrecarga de Informação.

b) A sobrecarga de informação mexe com aspectos físicos e psicológicos.

c) Vários sintomas como falha na memorização, na concentração e outros.

d) Reações físicas ligadas ao excesso de informação como dor de cabeça, etc.

e) Descrição de episódios e situações em que sentiram os sintomas já citados

(SABER, 2006, p. 202).

Sobre como a sobrecarga de informação afeta o rendimento profissional, Saber (2006) ressalta que

a) Muita informação exige que o jornalista tome decisões rápidas e acertadas

b) Se rende a rotina estressante e não consegue ver outra forma de trabalhar

c) Mudança de alguns hábitos para ter um melhor rendimento profissional

(SABER, 2006, p. 189)

Em vista da complexidade dos temas que envolvem a atividade e o ambiente de trabalho dos jornalistas, Saber (2006) propõe que outras pesquisas versem sobre os questionamentos não esclarecidos por sua pesquisa. Em sua análise:

Algumas questões permanecem e poderão ser aprofundadas em outras pesquisas, inclusive sendo adaptadas e aplicadas em estudos com outras categorias profissionais.

1) A sobrecarga da informação pode se apresentar de forma diferente, com menos ou mais intensidade dependendo do veículo no qual se trabalha, jornal, site ou TV?

2) É possível encontrar um novo método de organização operacional dentro das redações para que a sobrecarga não venha a afetar de forma tão negativa o jornalista e a notícia?

3) Com essa gama de informações o público leitor, o público telespectador sente alguma diferença no produto final sendo ele um programa televisivo, página eletrônica ou jornal impresso?

4) Qual é a análise que médicos especialistas fazem da categoria profissional o jornalista diante do ritmo de trabalho e do ambiente conturbado das redações?

5) A maioria dos jornalistas já se deu conta que o ritmo de trabalho mudou e que é preciso adquirir novas habilidades e ter outras posturas profissionais para não ficar submerso no oceano de informações? (SABER, 2006, p. 212)

\section{Efeito Fabril: as consequências da rotina produtiva pela Comunicação}

Pena (2006) estudou qualidade de vida do repórter, utilizando uma plurimetodologia, na qual analisou as relações de 54 jornalistas do estado de Minas Gerais e organizações nas quais trabalhavam. O objetivo foi o de criar uma epistemologia da qualidade de vida individual do repórter.

As rotinas produtivas estão estruturadas conforme uma concepção taylorista de organização do trabalho (PENA, 2006, p. 37). Tal fato levou as empresas de notícias a assumir o monopólio do trabalho intelectual, e relegar os repórteres à execução 
mecânica e parcelada de seu trabalho. $\mathrm{O}$ cérebro ainda é usado, mas equivale à mão do trabalhador. $\mathrm{Na}$ imprensa, esse processo assumiu a forma de cobertura jornalística, de imposição do "deadline" (o horário-limite industrial), produção computarizada, planos de metas, controle de erros, avaliações, planilhas do volume de produções. Para a autora, não existe uma visão de longo prazo que integre vários setores da organização e que trabalhe por processos, pensando em ir além da atividade de receber a pauta do editor, pesquisar nos arquivos, entrevistar alguém, escrever o texto e dar as tarefas por encerradas.

Pena (2006, p. 37-38) destaca que o ambiente organizacional, em Jornalismo, ignora os efeitos da fadiga e os aspectos humanos, psicológicos e fisiológicos das condições de trabalho. Pra a autora, a gerência exerce um controle real sobre o processo de trabalho, o que só poderia ser feito na medida em que a mesma dominasse o seu conteúdo, o procedimento do trabalhador no ato de produzir ${ }^{10}$.

As condições de trabalho nas redações costumam ser precárias. Ambiente abafado, tenso e trânsito intenso de pessoas são algumas características. Pena (2006) faz uma consideração prática pertinente sobre essas condições e sobre o nível de adesão ao jornal (também vista em Breed (1993), mas de modo bem teórico, quando estudamos Newsmaking). Veja:

\begin{abstract}
Os lugares de trabalho são "marcados" de várias formas: com fotos, com recortes colados na máquina de escrever ou embaixo do tampo de vidro da mesa, com vasos de plantas ou montanhas de material de referência. No momento de informatização dessas empresas, embora a mesa de trabalho continue a ter um titular que tem as chaves das gavetas, o computador é usado por quem chegar primeiro, o que é fonte de freqüentes atritos. Cada empresa jornalística tem um aspecto religioso: tudo se cumpre segundo as regras impostas, ninguém pode fazer o contrário porque é punido: sua teologia é de uma submissão total. O cumprimento da pauta sem discutir: um pedido da direção é uma ordem. Muitos sacrificam até suas férias. Existe um clima religioso nas redações porque os empresários da notícia exigem de seus jornalistas uma adesão quase religiosa, são muito estritos e fazem sentir seu poder hierárquico. Muitos jornais são caracterizados pela uniformidade de processos, unidade de produto e constância de ritmos, fundamentais para sua continuidade e definição de seu papel perante o mercado leitor e publicitário, e frente às instituições (PENA, 2006, p. 38).
\end{abstract}

Quanto ao fator tempo, em relação à agilidade na execução de tarefas, compreendemos que, na cultura organizacional, exista uma idéia de que os prazos sejam como linhas da morte (deadline), principalmente no fechamento de edições e textos.

\footnotetext{
${ }^{10}$ As representações da realidade no jornalismo informativo acabam por colocar a informação embalada em formato de Lead, Pirâmide Invertida e outros aparatos padronizados. Tal fato colabora para o controle social na redação, como vemos no estudo de BREED (1993), no arcabouço teórico de Newsmaking.
} 
Contudo, os prazos não têm a mesma aplicação em relação à jornada de trabalho. Para Pena (2006),

Normalmente, não há como desfazer o que ficou mal feito. Quando demoram muito em passar um relatório para chefia, logo depois ele não tem validade. É importante que o repórter esteja informado de tudo, portanto deve também ler todos os jornais para estar atualizado. Nas emissoras de rádio e televisão, geralmente todo repórter passa pela rádio-escuta. Nessa função, ele deve ouvir as outras rádios e também acompanhar os noticiários das emissoras de televisão, ou rádio, informando à chefia de reportagem quando um concorrente noticia algum fato que ainda não está sendo acompanhado pela emissora.

Outra característica das empresas jornalísticas é a rotina de trabalho, como no momento da chegada, que começa pelo ato de "bater o cartão", só na entrada, para ter controle do pessoal no cumprimento dos horários. Por que não controlam a saída também? As horas extras de trabalho, não contam? Ao longo do expediente, convém não se dirigir a um superior sem que ele tenha tomado a iniciativa. Ao fim do expediente, o jornalista deve aguardar autorização do chefe que terá suas razões para liberar membros da equipe no momento que convier. (...) O normal é esperar para ser dispensado(PENA, 2006, p. 3839).

Diferenciamos a noção de tempo da redação do tempo natural. Pena (2006) denuncia que quem sofre mais com os prazos e a ameaça iminente de morte (deadline) são os repórteres. Para a autora,

Em algumas emissoras até existe compensação das horas trabalhadas além do horário, mas nos jornais esta compensação de horas extras é esporádica. O trabalho é imposto em horários "anormais", como madrugadas, feriados, fins de semana. E quando a pessoa é demitida, é expulsa sem contemplações da "casa", voltando a ser o indivíduo da "rua". Os repórteres vivem imposições por parte das empresas, sendo submetidos e esquecendo que são seres humanos e não máquinas de fazer notícia. Existe, inclusive, até controle das chefias sobre seu tempo livre. Taylorismo e fordismo em vigência nas mídias modernas. $\mathrm{O}$ procedimento que revela o grau de produtividade a que é submetida uma notícia ou uma reportagem é a ditadura da pauta, que gera tensão para os repórteres. Muitas vezes, o material é inteiramente planejado (pautado), de acordo com interesses políticos e/ou comerciais. Portanto, o repórter deve preencher os vazios do texto com declarações convenientes (PENA, 2006, p. 40).

Pena (2006, p. 47) avalia que muitos repórteres ficam 280 dias fora de casa durante o ano sacrificando sua vida pessoal. O trabalhador é artesão de seu próprio sofrimento. Não resolvidas as necessidades e frustrações do trabalho, o repórter mantém sua pressão nas "horas vagas", que tendem a ser ocupadas pelo consumismo e a busca desenfreada de bebidas. Para a autora, o trabalho, em vez de ajudar a crescer e satisfazer a pessoa, colabora com a destruição da essência da pessoa, "fazendo do ser humano escravo de sua própria destruição".

A desvalorização dos repórteres nos meios de comunicação lhes causa angústia e decepção, conforme Pena (2006, p.40). Tal ação é incorporada pela empresa jornalística e institui uma espécie de "sonegação de estímulo" da cultura organizacional 
baseada na falta de investimento nos trabalhadores. A autora considera que "as políticas internas nem pensam como podem reduzir as tensões. A tensão é utilizada como estratégia para produzir qualidade de notícias". Em sua análise:

A desqualificação é a estratégia empregada nas empresas para obter maior docilidade e conseguir que [os jornalistas] aceitem o salário oferecido, pois profissional incompetente não pode fazer reclamações. Com relação à remuneração, existe uma discrepância salarial entre o "alto clero" das redações e o "baixo clero", que são os que ficam longos tempos nas empresas à espera de oportunidades e devem apresentar contínuas manifestações de dedicação seguidas de pedidos de aumento. Essa divergência de salário "mostra", para as camadas baixas da redação, como as promessas das empresas se realizam para os "bem-sucedidos". Suscitando aspirações obsessivas de ascensão que, com o passar do tempo, provocam desestímulos, desesperos, oportunismos, internalizações dos "fracassos" e, finalmente, saídas das empresas. A pressão começa com o processo da informação e passa pelo manejo da equipe - o que inclui contratação, promoção, demissão. Tudo isso está nas mãos do editor, em vários graus de poder. Normalmente, o editor tem autonomia para definir pautas e propor quais serão os repórteres especiais, embora, ao longo do dia, sejam feitas reuniões, com o poder central da redação, em que se administram espaços e temas. Existe outro desrespeito para o exercício da profissão: pois quase sempre os textos terminam escritos a várias mãos, ou seja, por ninguém. Não existe criatividade, nem autonomia (PENA, 2006, p. 48).

As empresas inibem a criatividade do jornalista. Se o profissional não se submeter à política, criam um ambiente de "lavagem cerebral" e "assédio moral" chamado de mau jornalista. A sobrecarga de trabalho, que quase sempre ultrapassa as oito horas diárias, causa frustração. Tal fato inibe outras atividades além do trabalho ${ }^{12}$.

Pena (2006) afirma que a precarização do trabalho em jornalismo é uma das principais contingências que levam ao sentimento de falta de valorização ${ }^{13}$.

Problemas mais graves também acontecem no ambiente de trabalho. Por vez, no caso das mulheres, há até assédio sexual. Miriam Caetano formou recentemente em jornalismo (dezembro de 2003). Como trabalho final, escreveu um livro-reportagem relatando a experiência de ter sido assediada sexualmente antes mesmo de ter o diploma de jornalista ${ }^{14}$.

\footnotetext{
11“"Margarita Barreto 24 , médica do trabalho, explica que existem práticas desprezíveis, porém bem conhecidas do mundo do trabalho, como "puxar o tapete" do colega, espalhar boatos maldosos sobre o superior ou desmoralizar o subordinado na frente da equipe. Atitudes desse tipo levam o nome de assédio moral e pressupõem perseguição sistemática ao funcionário, em uma espécie de terrorismo psicológico. Dos depoimentos dos repórteres, concluímos que o assédio moral nas empresas jornalísticas é muito comum".(VILAS, Sérgio Boas. Perseguição no trabalho é Assédio Moral. In: Revista Equilíbrio. Folha de São Paulo, 21 de fevereiro de 2002, pp.8-11. apud PENA, 2006, p. 48)

12“"Muitos têm o sonho de chegar a ser escritores e não conseguem escrever por falta de tempo". (PENA, 2006, p. 48)

${ }^{13}$ É comum o jornalista trabalhar em dois empregos para reforçar orçamento familiar. O enxugamento das redações devido à onda neoliberal e informatização, nos anos 90, tirou muitos postos de trabalho e aumentou a oferta de mão-de-obra. Com isso, os salários caíram e houve certa precarização das condições de trabalho.

${ }^{14}$ CAETANO, Miriam Lins. Lágrimas de Álcool: as diversas faces experimentadas pelo alcoólatra.
} 
Miriam Caetano conta que teve como "forte motivo para me manter sóbria" o fato de alguns superiores acharem que ela estivesse disponível para insinuações relativas a assédio sexual. A jornalista se sentia "desprotegida e insegura pelas apelações dos chefes". O momento mais sofrido de sua história foi quando morou na entrada de uma favela por falta de recursos. Para agravar a situação, durante essa fase, engordou quase 10 quilos por comer apenas bolacha recheada nas refeições (PENA, 2006, p. 67).

O caso de Miriam Caetano ilustra, de modo extremo, algumas conseqüências da vida real, oriundas do labor e do ambiente de trabalho jornalístico, que muitas vezes não são percebidas nos arcabouços teóricos. Em uma parte de seu relato, a jornalista expressa a influência da rotina produtiva na sua vida: "ficava inchada com o calor e o excesso de trabalho que me consumia na produção de um programa das oito da manhã às dez da noite. E a falta de recursos me incomodou quando um dente quebrou e não tive dinheiro para arrumá-lo no dia. Meu rosto ficou inflamado e a dor era insuportável" (Idem).

\section{Considerações finais}

O presente artigo não tem o objetivo de fazer uma nova afirmação científica sobre Newsmaking, mas, sim, de oferecer um outro ponto de vista ao seu leitor. Tentamos ir além do que conhecemos por Gratificações e Constrangimentos no ambiente organizacional, como trata o arcabouço teórico de Newsmaking. Nossa intenção, em momento algum, foi o de refutar, confirmar ou questionar postulados teóricos deste ramo da Sociologia dos Emissores. Quisemos apenas compilar alguns trabalhos contundentes que exemplificassem elementos que a comunidade científica sempre tem contato, em Comunicação, mas não debruça sobre os fatos de um modo mais prático e quantitativo.

Tivemos contato com todo este material quase que exclusivamente por comutação bibliográfica. Diante da riqueza destas pesquisas, pouco divulgadas no meio acadêmico da Comunicação, tomamos a iniciativa de fazer tais informações circularem por meio deste artigo compilativo. Recomendamos a leitura de Ferraciolli (2000), Beraquet (2005), Saber (2006), Pena (2006), Nassar (1990), Heloani (2005), além dos

Livro-reportagem apresentado para obtenção do título de bacharel na habilitação em Jornalismo do Curso de Comunicação Social - Universidade de Uberaba, dezembro de 2003. 
autores citados. Finalizamos chamando a atenção de pesquisadores para parcerias com outras áreas do conhecimento que possam ajudar a entender fenômenos no mundo do trabalho jornalístico e até somar dados que exemplifiquem o arcabouço teórico Newsmaking, como nesta experiência que ora oferemos.

\section{Referência bibliográfica}

BERAQUET, Maria. Qualidade de vida de jornalistas da macro região de Campinas-SP. Dissertação 2005 (Mestrado em Comportamento Social e Psicologia da Saúde), UCDB.

CAETANO, Miriam Lins. Lágrimas de Álcool: as diversas faces experimentadas pelo alcoólatra. Livro-reportagem apresentado para obtenção do título de bacharel na habilitação em Jornalismo do Curso de Comunicação Social - Universidade de Uberaba, dezembro de 2003.

FERRACIOLLI, Márcio. "A gente nem comenta porque isso, no dia a dia, acontece com todo mundo": trabalho e sofrimento - o caso dos jornalistas. 2000. Dissertação (Mestrado em Psicologia Social), UFSC.

HOHLFELDT, Antonio; MARTINO, Luiz C.; FRANÇA, Vera Veiga. (orgs.). Teorias da comunicação: conceitos, escolas e tendências. Petrópolis: Vozes, 2001.

PENA, Janis. Em busca da qualidade de vida individual do repórter: compreensão das mediações presentes no processo comunicacional dos jornalistas. 2006. Tese (Doutorado em Comunicação), USP.

SABER, Marina. Efeitos da sobrecarga da Informação no cotidiano de jornalistas em Campo Grande - MS. Dissertação. 2006. (Mestrado em Ciência da Informação e Documentação), UNB.

VILAS, Sérgio Boas. Perseguição no trabalho é Assédio Moral. In: Revista Equilíbrio. Folha de São Paulo, 21 de fevereiro de 2002, pp.8-11.

WOLF, Mauro. Teorias das Comunicações de Massa. São Paulo: MARTINS Fontes, 2003.

Recebido em : 26 jul. 2012

Aprovado em: 17 set. 2012 